\title{
Climate change, food security and sustainable human development in Nigeria: A critical reflection
}

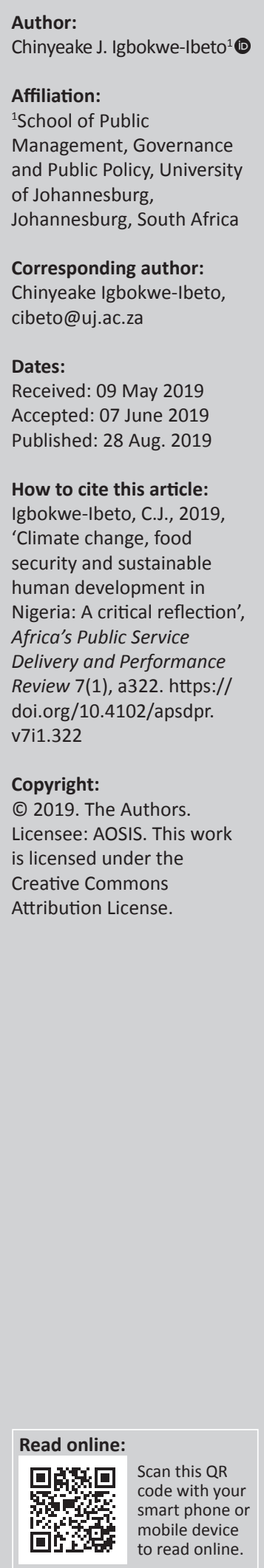

Background: Nigeria is abundant in numerous agro-ecological resources, which should make it a major exporter of food items in the world. Regrettably, it has become a major food importer as a result of food scarcity. The state of food production in the country is worsened by the phenomena of climate change and global warming. These developments have deleterious effects on agricultural activities in general and food production in particular. While there are policies and agencies in the country to combat these developments, it appears they have proved ineffective in the face of increasing inconsistency in government policies, climate change and global warming. The effect of all these phenomena on human development cannot be overemphasised. A nation that cannot feed its population cannot promote development.

Aim: It is against this background that this article, within the framework of dependency theory, examines the issues of climate change, food security and sustainable human development in Nigeria.

Setting: This research is descriptive in nature in the sense that it provides a detailed account of policies on climate change and food production in Nigeria. It is also exploratory because over 29 research studies were consulted and analysed in order to establish the relationship between climate change, food security and sustainable human development in Nigeria.

Methods: This article utilises qualitative, descriptive research methods. This article, which is theoretical in nature, drew its arguments on both primary and secondary data, which included textbooks, journal publications and internet sources.

Results: This article argues that unless concrete efforts are made to mitigate the effects of climate change and ensure increased food production, the country may experience worse cases of food crisis and human underdevelopment.

Conclusion: Consequently, the article recommends, among others, environmental impact assessments before, during and after industrial production activities.

Keywords: Climate change; development; food security; sustainability; Nigeria.

\section{Introduction}

Nigeria has the human and material resources to be in the league of developed countries, the characteristics of which are higher contribution of industrial and service sectors to national income, large portion of labour force depending on manufacturing and service centres, use of modern and advanced techniques of production, high standard of living, high per capita income, low incidence of poverty, narrow income inequality, low growth rate of population, low level of unemployment, presence of infrastructural capabilities, high rate of savings and capital formation and export of largely industrial services and products (United Nations Development Programme [UNDP] 2018). Despite its enormous potential, it remains a 'crippled giant' (Osaghae 2011:4). One area where it has failed to live up to expectations is feeding its population. While population increase is a common phenomenon and grows in arithmetic progression, food production is growing in geometric progression and therefore does not match population increases. This has led to what is known as a food crisis, thus leading to high prices of staple foods in the country. Many Nigerians currently cannot meet their food requirements because food prices have increased beyond the reach of most citizens, thereby making the people susceptible to hunger, malnutrition, diseases and other health hazards (Akuwudike, Igbokwe-Ibeto \& Achilike 2018:36). Climate change also reduces their potential to engage in productive human activities such as farming, fishing and other physical and mental activities (Emefiele 2018:36; Olufemi 2018:1-2).

The current food crisis, however, is not limited to Africa alone. All over the world, there is an issue of food insecurity. In Nigeria in particular and Africa in general, the phenomenon has assumed 
frightening dimensions (Adebayo \& Abubakar 2015:22; Emefiele 2018:36). On a continent devastated by terrorism, fighting among ethic nationalities, famine, drought and disease, the present food shortage seems to add to the litany of crises besetting the continent (Akhakpe 2018:213). The discovery of oil dealt a serious blow to the structure of the economy as it relegated agriculture, previously the mainstay of the Nigerian economy, to the background.

The attainment of independence in 1960 and the discovery of oil were expected to bring some relief to the people in terms of the improvement of their standard of living. This could, however, only have been possible if peopleorientated policies and programmes were pursued and realised. Regrettably, successive governments, particularly under the military regime, paid lip service to programmes aimed at producing enough food for feeding its population (Adebayo et al. 2012:108). Moreover, the democratic government since 1999 to date has not been proactive in addressing climate change and producing sufficient food for its citizenry as they all paid lip service to agriculture, with many billions of naira spent without any impact. A number of studies (Adebayo \& Abubakar 2015:21; Olaniran 2012:6) have been conducted and solutions suggested, but the problem remains endemic and persistent in Nigeria. This article therefore seeks to join the debate by addressing the following research questions: how has the government responded to climate change and insufficient food production in Nigeria? What problems confront these remedial steps? and What can be done to mitigate these challenges?

To address the subject matter under investigation, this article is divided into six sections. The first section examines conceptual and theoretical issues. Secondly, it conducts a historical analysis of policies on food production. Furthermore, it traces the evolution of the Nigerian economy, particularly in the area of food production and security. It then discusses the effects of climate change and food insecurity on human development and the efforts of the government through its various agencies to tackle the problem. Thereafter, it discusses the challenges facing the government in managing the agricultural sector and climate change. Lastly, some remedial steps to mitigate the present food crisis and climate change are suggested.

\section{Methodology}

This article is qualitative in nature, using secondary data to examine the issue of climate change, food insecurity and sustainable development in Nigeria. The research is descriptive in nature in the sense that it provides a detailed account of policies on climate change and food production in Nigeria. It is also exploratory because the article attempts to discuss the nexus between climate change, food insecurity and sustainable human development in Nigeria. This article, which is theoretical in nature, drew its arguments from both primary and secondary data, which included textbooks, journal publications and internet sources.

\section{Conceptual framework}

In order to avoid ambiguity in the interpretation and understanding of certain concepts, it is customary to begin an academic investigation by examining the conceptual and theoretical contours of the subject matter of analysis (Igbokwe-Ibeto, Osakede, Nkomah \& Kinge 2016:345). Climate change as a concept has several definitions. Unlike other concepts, it has not generated much controversy as to its actual meaning. Climate change is a complex interaction between earth's atmosphere, stratosphere and troposphere on one hand, and land biosphere on the other hand (Allen 2004; Osakede, Ijimakinwa \& Adesanya 2016:3). Climate change can also be seen as a change of climate that is attributed directly or indirectly to human activity that alters the composition of the global atmosphere and which is, in addition to natural climate variability, observed over comparable time periods (World Bank 2012). One of the effects of climate change is global warming. It has been argued that global warming is one of the most serious environmental challenges that confront mankind today (Olufemi 2018:2; UN 2011; World Bank 2012). The 2011 and 2018 floods in Nigeria in which a number of states were almost submerged by floods and crops worth billions of dollars were destroyed are a typical example of climate change.

An analysis of the above definitions suggests the threat posed by climate change and global warming and therefore emphasises the seriousness and urgency for countries to develop policies and programmes to combat the scourge and mitigate its effect on the environment and human development. The increasing intensity and frequency of extreme weather conditions, such as droughts, floods and other effects, speak largely to the urgent need to seriously address the threats posed by climate change. The international response to climate change has evolved around the United Nations Framework Convention on Climate Change and its Kyoto Protocol, which together provide an institutional framework for action on a global scale. Food insecurity has been identified as one of the most serious effects of climate change (Olufemi 2018:2).

There are so many definitions of the concept 'food security' but the benchmark is that given by the Food and Agricultural Organisation (FAO) in 2001. According to FAO (Burke \& Lobell 2010:14), food security can be seen as a situation where and when all the citizens at all times have socio-economic and physical access to sufficient, safe and nutritious food that meets their dietary needs as well as food preferences for an active and healthy life. An examination of this definition indicates that food security involves having the food needs and wants on individual basis. Conventionally, this definition according to Burke and Lobell (2010:14) is further subdivided into three main components that include availability of food, access to food and utilisation of food. While availability to food refers to the physical presence of food, access to food refers to having the means to provide food through purchase 
or production, and utilisation of food refers to the appropriate nutritional content of the food and the ability of the body to use it effectively (Burke \& Lobell 2010:14).

Food is one of the basic necessities of life. It is needed for strength, human growth and development. Every country in the world desires to feed its population and to export food to other nations. Food production is one of the outcomes of agricultural activities. If food is to be abundant for local consumption and export, its production must be developed. In a society where there is agricultural development, the people can feed themselves and ensure their own development (Akhakpe 2018:213). Human development can be operationalised as the ability to expand human capabilities by expanding the choices people have to make in the process of creating life (Thakrar \& Minkley 2015:132). One of the needs that must be met to realise human development is food. Once this need is met, people are prepared to challenge and conquer other needs. As people develop their capabilities, they are able to challenge and possibly conquer their short lifespan and have access to renewable resources needed for decent living.

Once the processes of expanding human capabilities are carried out on a consistent basis, they create sustainable development. Sustainable development can be defined as development that meets the needs of the present generation without compromising the ability of future generations to meet their own needs (Anazodo, Igbokwe-Ibeto, Osawe \& Nkah 2014:117). When viewed from this angle, sustainable development implies economic growth and the protection of environmental quality, each of which reinforces the others. Such a relationship must not, however, diminish the prospect for future generations to enjoy quality of life as good as the present generation. Certain developments are, however, mostly outside the control of man. One of them is climate change.

Climate change and variability are processes of alteration of climate conditions indicated by factors such as increased frequency of heat and ground-level ozone. While this development may not always cause a reduction in food production, the increased potential for droughts and heat waves could pose serious challenges, particularly to food production. The challenge facing the human community is therefore how to manage these developments while at the same time increasing agricultural production.

\section{Theoretical underpinning}

One of the theories that explain agricultural development is modernisation theory. The theory can be represented by a production function showing 'agricultural output as a function of various inputs. Such inputs for modernising agriculture are institutional in nature and include research and educational facilities'. These facilities and services that can be regarded as 'essentials for development' include constantly changing technology, production incentives, local availability of supplies and equipment, markets for farm products, transportation, credit systems and land reforms (Elegalam 2009:22). The pursuit of these goals in Nigeria, however, has not created quantitative changes in food production in particular. This has made the search for other theories to explain the state of food production necessary.

For the purpose of this article, the dependency theory is considered the most potent and heuristic for interrogating the subject at hand. The major thrust of this theory argues that the postcolonial state is a law-and-order state. This allows the state to use coercion to formulate policies and gain obedience from the citizens. The forceful use of state power has also brought to bear on its trade patterns. Farmers are forced to produce for export, and they depend on the metropolitan to determine the prices of their produce. As Ake (1981:86) argues, this dependence reflects the exploitative structural integration of the colonial economy to the capitalist system of the metropolis. This integration has failed to bring relief to farmers and other producers of allied goods. On the one hand, farmers cannot produce enough to eat, and on the other hand, the prices of their goods fall constantly. The failure of the country to delink from this capitalist order can be said to be the problem of the country's leaders and not entirely that of the capitalist West.

\section{Historical analysis of policies on food production in Nigeria}

Food is a basic necessity of life. Maslow's hierarchy of needs considers food as one of the basic necessities of human being. Abraham Maslow's hierarchy of needs is always displayed as a ladder or pyramid. The lowest levels of the ladder are made up of the most basic necessities of life, while the most complex needs are at the top of the ladder. Needs at the lower stage or bottom of the ladder are referred to as basic physical requirements that include the need for food, water, sleep, sex and warmth. Once these lower levels of needs of the pyramid have been met, people can move on to the next level of needs, which are for safety and security (Maslow 1943). From the foregoing analysis, it is clear that food and food security is a component of sustainable development. The basic function of every government is to provide the basic necessities of life to the citizens to enable them to live a happy and secure life. As the social contract theorists put it, the role of the state, through its agency government, is to make possible the full moral and human development of the individuals who comprise it and that it could demand complete loyalty, even to the extent of requiring the sacrifice of an individual's life in war (Gamble 1981:65).

One area where full moral and sustainable human development can be realised is in food production. This is evidenced by the fact that not only is food required for human existence, but any country that cannot feed its citizens is looked down upon by the community of nations (Akhakpe 2018:213). Thus, every nation strives towards self-sufficiency in food production. To this end, governments in Nigeria since independence have devised various policies directed towards raising the level of food production. This is often part of 
macro-economic policies. However, after more than 50 years of the pursuit of this goal, what has happened to agriculture and food production? To answer this question, it is important to first highlight some of the efforts made by the state in this direction.

Between 1980 and 2000, Nigerian governments at the federal level put forward comprehensive policies and policy instruments to develop and improve the performance of the country's agricultural sector, over a 15-year period. One of the key objectives of this programme was to ensure a rapid increase in food production with the aim to adequately feed the growing population and eliminate or drastically reduce food importation. A basic objective in this respect was the attainment of a $4 \%$ growth rate of the sector, so as to achieve self-sufficiency in food production by 1996 (Olaniran 2012:7). To realise this aim, some strategies were put in place, including farm input supply and subsidies, agricultural credit through banks and the mechanisation of agriculture by providing tractors, implements, extension service workers, water and irrigation resources and so on.

An assessment of Nigerian government's efforts, however, presents a mixture of success and failure. Failure appears to be more evident as indicated by the present food crisis. There are a number of reasons for this failure. Some of them include the top-bottom approach to policy initiation and formulation regarding agriculture, the inconsistency of government policies on agriculture, political instability, the tendency of the elite to pursue selfish accumulation to the detriment of Nigerians and delays in the release of funds meant for food production (Akhakpe 2018:217).

These constraints were not inevitable and may have been easily resolved, but for the structure of the country's political economy. For instance, the popular participation theory would argue that there is insufficient participation of the people in economic activities, while the liberal political economy theory contends that distortion in the flow of resource allocation by African countries is at the root of their food and economic crises. The Marxian political economy theory contends that the economic sub-structure of society determines what happens at the level of governments' policy formulation, social relations of production and so on (Ake 1981:81). The liberal and Marxian political economy theories point to the fact that food production has not been given the attention it deserves in Nigeria.

\section{Agriculture and food security}

Nigeria, according to European Center of Sustainable Development (ECSD 2016) with its abundant agro-ecological resources and diversity, has become one of the largest food importers in sub-Saharan Africa. Agriculture as the major supplier of food accounts for over 70\% of the nation's food supply (National Bureau of Statistics 2017:5). Food production is just one aspect of this sector, yet it is one of its most important parts. Food is considered vital to all human life, and one of the basic functions of governments all over the world is to ensure that their citizens are well fed by ensuring that adequate and affordable food reaches the people (Adebayo et al. 2012:109; Bemisaya 1985:58).

Based on this fact, it is customary for governments at all levels to put forward policies on food production. The policies of the precolonial era emphasised food production mainly for subsistence. The various social formations in Africa produced different kinds of crops for domestic consumption. The method of farming was rudimentary as hoes and cutlasses were, and still are, the major instruments used for farming. However, the interesting aspect of this era was that these methods of farming were sufficient to support the demand of the local population, and in some cases, surplus was exchanged for other goods that were in short supply in sub-Saharan Africa. Thus, hunger and food crises were not popular and frequent themes in the discourse of this era. In other words, there was enough food to feed the populations of the various peoples of Africa. This was the situation before the arrival of the Europeans in Africa.

The sojourn of the Europeans first into the coastal areas and later into the inlands brought structural changes to the character of the economy. The colonial economy 'concentrated only on economic activities beneficial to the colonial state, and was thereby disarticulated theoretically'. According to the Political Bureau Report (Federal Government of Nigeria [FGN] 2007:10), it 'promoted the interests of the centers of activities - the urban settlement and thereby neglected the rural mass settlements'. This practice alienated the rural (peasant) farmers who were the proverbial geese that laid the golden eggs. This began a process where citizens lost hope in the rural areas as the domains of material reproduction and development. They began to regard the urban centres as their promised land where there was greener pasture. Expectedly, agriculture became affected as production of food for subsistence gave way to production for export and urban consumption. As the Political Bureau Report (FGN 2007:10) states, production for export and the sale of imported European commodities increased.

Marketing boards were set up in three regions of Nigeria, namely the Northern Region, Eastern Region and Western Region, mainly to facilitate food production for export. Later, the Mid-Western Region was carved out of the Western Region and was assigned its role in the process. One feature of this era was that each of these regions specialised in the production of a particular cash crop (Okigbo 2007:47). The goal was to ensure that there was a steady supply of these commodities to Western Europe. Although some of the objectives of these commodity boards were to improve crop production through better funding and research on seedlings, to boost production and improve the condition of farmers, among others, they were also used to sustain the colonial masters' reserves and balance their trade relations. Because these objectives were not genuine, its successors used the funds to line their own pockets and financed political activities (FGN 2007:8). 
Flowing from the above, the indigenous political leaders also realised the need to use the state as an instrument of material accumulation. Every policy and programme embarked upon by the ruling class was designed to consolidate their material base and secure power. Thus, the postcolonial state retained the structures bequeathed by the colonial administrators at independence. The production of goods and services by industries, especially the import-substitution ones, was meant to extend the goals of metropolitan capital. As the Political Bureau Report (FGN 2007) argues, the:

\section{... mere replacement nature of these industries rather than undermine the dependent capitalist political economy of the country at the expense of peasant and petty commodity production, they were also, understandably in location and concentration, based towards the urban centers at the expense of rural areas. (p. 12) \\ The nexus between climate change, food security and human development}

The export and distributive orientations of the country's political economy managed to provide food for local consumption, complemented by the import of some food items. Despite this, the country has not been able to achieve self-sufficiency in food production, which is the goal of all countries that aspire to greatness. In terms of the provision of basic food items like rice, the country has failed to achieve its targets. Therefore, with little change in climatic conditions such as global warming, the country's food supply is in chaos. While there have been efforts by the government in the past to boost the production of basic food items, such as Operation Feed the Nation (OFN) and Green Revolution, policy failure, poor funding and lack of sincerity and political will on the part of the country's leaders have made the production of staple foods suffer a decline (Akhakpe 2018:216; Akuwudike et al. 2018:47).

The global food crisis has caught Nigerians unprepared on how to manage the situation. While a combination of factors outside state policies may have led to the decline in agricultural yield, such as lack of proper irrigation systems, storage facilities, poor seedlings and inadequate supply of fertilisers, climate change has compounded the problem of agricultural production, especially food supply for local or domestic consumption. Changes in rainfall can affect the soil erosion rate and soil moisture, both of which are important for crop yields (Adebayo \& Abubakar 2015:26; Moreland \& Smith 2012). Although, moderate rainfall in some areas could be advantageous to food production, recent reports from some northern states indicate that 'torrential rains destroyed lives and 5,787 farmlands in Bauchi State in August 2009' (Akhakpe 2018:212). Similar occurrences were experienced in 2011 and 2018 in most coastal states of Nigeria, usually referred to as the food basket of the nation. Climate change has been identified to be among the leading causes of rising global hunger (FAO 2017; UN 2018).

Conversely, where the rains are not forthcoming, agricultural yields are stunted. This is because Nigeria's agriculture is mainly rain fed and the country has not taken full advantage of its irrigation potential, which is estimated between 2 and 2.5 million hectares (ECSD 2016). These developments in agriculture in general and the production of basic food stuff in particular have led to increases in the prices of food items that eventually find their way to the market.

Table 1 indicates the consistent price increases in six staple food items. From all indications, the trend is bound to be maintained given the low yields reported by most farmers in the preceding year across the country. Drought that is being experienced in some northern parts of the country is a pointer to this claim. The use of irrigation systems to boost agricultural yield is not well spread and popular among farmers.

According to the International Monetary Fund (2015), with the gross domestic product in market exchange rate terms at $\$ 493.8$ billion in 2015, Nigeria ranked as Africa's largest economy and could be the ninth largest global economy by 2050. Prior to the recent decline in the price of crude oil, Nigeria enjoyed strong economic growth at a compound annual growth rate of $5.3 \%$, post rebasing. This growth did not, however, translate into social and sustainable human development as abject poverty and inequality levels persist. The effects of all this on development have been debilitating. Many Nigerians depend on agriculture as their means of livelihood. They derive income from it, and use it to pay school fees for their children and relatives and to meet other sundry expenses. With the decline in agriculture, fewer resources are available for meeting these needs.

In addition, food is needed by everyone to maintain their health. A population that does not eat well is susceptible to diseases and poverty. The decrease in food production in recent years has made Nigeria one of the poorest countries in the world. According to the report of American-based International Food Policy Research and a German nongovernmental organisation called Agro Action, Nigeria

TABLE 1: Market survey from 2010 to 2017.

\begin{tabular}{|c|c|c|c|c|c|c|c|c|c|c|}
\hline \multirow[t]{2}{*}{ Item } & \multicolumn{8}{|c|}{ Year } & \multirow[t]{2}{*}{ Quantity } & \multirow[t]{2}{*}{ Remark } \\
\hline & 2010 & 2011 & 2012 & 2013 & 2014 & 2015 & 2016 & 2017 & & \\
\hline Flour & 5000 & 5600 & 5600 & 5600 & 6800 & 6900 & 6400 & 8950 & $50 \mathrm{~kg}$ bag & Egan Market \\
\hline Sugar & 6000 & 6500 & 6500 & 6500 & 7900 & 6550 & 8400 & 13650 & $50 \mathrm{~kg}$ bag & Jos Main Market \\
\hline Gari & 1600 & 1600 & 1600 & 4400 & 4400 & 5600 & 7500 & 8000 & $50 \mathrm{~kg}$ bag & Eke Awka Market \\
\hline Beans & 3000 & 3000 & 3000 & 3500 & 3700 & 4000 & 7000 & 14000 & $50 \mathrm{~kg}$ bag & Ikotun Market \\
\hline Rice & 4500 & 4500 & 5550 & 6500 & 8000 & 7000 & 13000 & 20000 & $50 \mathrm{~kg}$ bag & Igando Market \\
\hline Yam & 150 & 210 & 220 & 250 & 330 & 450 & 500 & 800 & A tuber & Ogbote Market \\
\hline
\end{tabular}


ranked 84th of 119 developing countries on the Global Hunger Index (Von Grebmer \& Hossain 2017). According to this report, deficiencies in vitamin A, iron and other essential macro-nutrients continue to pose a huge public health problem that results in illness, reduction in school enrolment, low productivity and premature death. The population involved in agriculture is also ageing (Akhakpe 2018:214; Igbokwe-Ibeto, Akhakpe \& Oteh 2012:372), and this ageing population of farmers is not able to produce for the whole nation and for export purposes (Igbokwe-Ibeto, Okoye \& Nnaji 2018:115).

Therefore, in terms of human development, Africans are still lagging behind. While many developing countries have overcome the problem of food, water and housing to a considerable extent, Nigeria is still struggling with these elementary aspects of development. The Human Development Index (HDI) (UNDP 2018:4) ranked Nigeria 177th of 199 countries on the Quality of Life Index. According to this index report, which includes both the developed and developing countries of the world, 'the index shows that Nigerians are poorer than they were two years ago and they live even shorter lives' (UNDP 2018). What has been the response of the government to these unfolding situations? This is the subject of analysis in the section that follows.

Climate change is a global phenomenon that will persist for some time to come. One of the factors that induce climate change is the twofold increase of carbon dioxide in the atmosphere (Adebayo et al. 2012:112; FAO 2017; Moreland \& Smith 2012). This is likely to be worse in areas where excessive mining and exploitation of resources are carried out. Gas flaring and other kinds of pollution that characterise oilexploration activities contribute to the depletion of the ozone layer, thereby causing global warming. Such a global rise in temperature is expected to scientifically change the pattern of rainfall, soil moisture and other climatic factors related to agricultural productivity. The distribution of rainfall in recent years has not been supportive of agriculture and food production (Adebayo \& Abubakar 2015:27; Akhakpe 2018:218).

\section{Challenges confronting state intervention initiatives}

This section examines the present food insecurity, climate change and human development, and state interventions to combat them. Right from (military era) 1976, government policy on food production has tended to place its implementation in the hands of public servants and leaving those directly affected by the policy out of the scheme of things (Akhakpe 2018:214). Because of this non-inclusiveness, implementation often falls short of expectations. Although successive governments have devised well-articulated policies on food production, such as OFN, Green Revolution and the Presidential Initiative on Staple Food Production, government have not been able to manage these polices to achieve their goals (Anazodo et al. 2014:162). The delay between policy formulation and implementation is often too long to allow for efficient and effective policy implementation. Also, much-needed funds for implementing these policies were never made available on time to ensure effective implementation (Igbokwe-Ibeto et al. 2012:372). The paucity of funds for agricultural development or lack of proper management of available funds leads the failure of the state to fully implement projects and programmes meant to improve the conditions of the underprivileged in society (Akhakpe 2018:214; FAO 2011). The lack of equipment to manage climatic changes is a demonstration of the fact that the right priorities are not pursued.

The structure and organisation required to tackle problems emerging from environmental occurrences like the current global warming, climate change and ozone layer depletion are not available (FAO 2017). Where they are available, they are managed by personnel who are poorly mobilised. As a result, they are not truly committed to their work schedule and details (Igbokwe-Ibeto et al. 2018). Also, the perception of the state as a distributive agency has not changed radically from what it was in the colonial era. In some quarters, government business is seen as a white man's job and its resources are regarded as inexhaustible (Fatile \& IgbokweIbeto 2012:18).

In addition, the development paradigm in Africa is an obstacle to development. Development that can lead to abundant food production is perhaps not yet in place on the continent (Anazodo et al. 2014:119). Most African leaders are still preoccupied with fighting for survival in office, the use of coercion to put fear in the opposition and engaging, in selfish accumulation of wealth. In all these, scarce resources are diverted to uses like in accumulating arms for fighting ethnic wars and suppressing dissent (Akhakpe 2018:215). The next section provides recommendations to overcome the barriers discussed in this article.

\section{Climate change, food security and sustainable human development in Nigeria: The way forward}

Meaningful progress in food production cannot be achieved without a major review of the development strategies in Nigeria and the ideology of development itself. Ideology provides the psychological power with which people communicate and evaluate ideals and propose among themselves and their environment, as well as between them and their government (FGN 2007:10). Conversely, development is about making qualitative and quantitative changes to the living conditions of the people. There is a sense in which it can be argued that the relationship between ideology and development is dialectical. Ideology organises people both perceptively and actively around what it is that should be transformed or developed (FGN 2007:10). In this regard, it is agriculture and food production.

The present development paradigm of the Nigerian government is not geared towards self-sufficiency and self- 
reliance. It is orientated towards the metropolitan, which serves as its model of development (Adebayo \& Abubakar 2015:23; Igbokwe-Ibeto et al. 2018:16). However, since the 1970s and the 1980s, this has proved to be a failure. There is a need for a paradigm shift to a socialist framework of development, or better still, welfarism that would make the people's welfare and well-being the primary concern of the government and put control of the government effectively in the hands of the people (Osaghae 2011:201). In this way, some of the problems of food insecurity, provision of social amenities and so on can be managed effectively.

The present land use system does not favour farmers. Land is not available to those willing to farm. The present Land Use Act must be reviewed to make land available to all adult males and females for cultivation (Akhakpe 2018:220). Yet, for those whose lands were compulsorily acquired by the government, adequate compensation should be paid to them to enable them to find alternative land for farming.

As part of the government policy of funding agriculture, proper monitoring of the process of obtaining loans or aid should be made clear to ensure that monies are used appropriately for their target populations. In the past, government funds meant for agriculture went to 'bureaucratic and political farmers' who appropriated such funds for other uses. Following the poor performance of the agricultural sector, the federal government in 2011 launched a policy document known as the Agricultural Transformation Agenda (ATA). The ATA was powered by e-Wallet, an electronic distribution channel that provided an efficient and transparent system for the purchase and distribution of agricultural inputs based on a voucher system (Solomon \& Marcin 2014:166). The programme boosted crop and agricultural productivity and profitability, improved agroinput distribution and marketing by the private sector, created a farmers' database that boosted the farmers' income, increased the standard of living and had a direct effect on poverty reduction (Solomon \& Marcin 2014:164). However, the Buhari-led All Progressives Congress (APC) government jettisoned this laudable programme. The government should sustain the effective policies and programmes of its predecessors and find a way of targeting the real peasant farmers and making them active in food production and other forms of agricultural activities.

Similarly, micro-financing of agricultural activities could be very potent in resolving the present food crisis in the country (Akuwudike et al. 2018:38; Adebayo \& Abubakar 2015; Moreland \& Smith 2012). While the government has done this to some extent in the past, it should be made more flexible for farmers to access soft loans from banks, insurance companies, the Central Bank of Nigeria, community banks and microfinance institutions across the country. The procedures for obtaining loans from banks should be simplified for the sake of farmers - the majority of whom are uneducated.

The phenomenon of rural-urban drift is in no way abating. Given the enormity of the challenges facing the rural areas, there should be a Marshall Plan for these areas with a view of bringing them closer to modernity (Anazodo et al. 2014:169). Without doubt, governments have in the past made efforts in this direction, but it would appear they did not have much impact on the people. Therefore, there is a need for proper evaluation and reformation of policies on rural development in the country. The government should intensify efforts in the provision of basic social amenities that remain low and absent in most urban and rural communities. In many rural communities, social amenities such as schools, health care services, water and roads are in short supply or non-existent. There is a need to restrategise to ensure that every community in Nigeria benefits from such social infrastructure.

The present climate change undoubtedly has a negative impact on agriculture and human life. It must be managed well for sustainable development to be realised (Burke \& Lobell 2010; Logan 2015). Managing its effects cannot be left to government alone, however. There must be a role to play for everyone in society. The way people burn bushes and wood, search for fuel, manage their cars and so on can be reduced to limit the effect or impact of greenhouse gases on arable land and the life of the people (Akhakpe 2018:216). The unconducive environment created by climate change reduces the abilities of the people to engage in active enterprises.

There are also enough reasons to believe that governments have been lacking in their regulatory functions, especially how they affect the use of the environment. This explains why environmentally friendly approaches are not made the hallmark of industrial activities (Akhakpe 2018:211). Therefore, it must be emphasised that Environmental Impact Assessments (EIAs) should be made compulsory before, during and after industrial production activities. Unfortunately, the legal mechanisms for managing the environment remain blunt or inactivate, bringing in the process many sorrows and pains to communities where these activities are carried out (Burke \& Lobell 2010; Logan 2015). In Nigeria, the goose that lays the golden eggs is not taken care of, and where there is compensation, it is not consistently followed through by the government, thus creating opportunities for bureaucratic and political elites to hijack and mismanage funds meant for compensation.

\section{Conclusion}

The state of the food crisis in Nigeria today is alarming. The prices of food items have increased astronomically, and the government appears to be unsure of what to do to resolve the crisis. Matters are made worse by the effects of global warming, which have debilitating consequences for the already chaotic food production situation in the country. The government should rise up to its responsibility by providing safety nets in the short term, as discussed in the body of the article. Managing the present situation should not be left to the government alone as it requires collective efforts by all in society. Proper management of the environment in the best 
interest of all, irrespective of sex and age, is surely a step in the right direction. A statist approach to food production should be discouraged and the government should increase efforts to reorient the populace regarding the need to embrace food production for both internal consumption and export. Climate change is a global phenomenon; the government should make concrete plans to mitigate the effects thereof on food production and human development.

\section{Acknowledgements}

The author is grateful to all authors whose works were cited and the entire academic community of the University of Johannesburg and Nnamdi Azikiwe University. Yet, the author cannot forget his amiable host Prof. Danielle Nel for her care and concern for his progress.

\section{Competing interests}

The author declares that he has no financial or personal relationships that may have inappropriately influenced him in writing this article.

\section{Author's contributions}

The author declares that he is the sole author of this research article.

\section{Ethical consideration}

This article followed all ethical standards for carrying out research without direct contact with human or animal subjects.

\section{Funding}

Funding for this study was provided by the University of Johannesburg, South Africa.

\section{Data availability statement}

Data sharing is not applicable to this article as no new data were created or analysed in this study.

\section{Disclaimer}

The views and opinions expressed in this article are those of the author and do not necessarily reflect the official policy or position of any affiliated agency of the author.

\section{References}

Adebayo, A.A. \& Abubakar, S.Y., 2015, 'Assessment of climate change in the Savannah Sugar project area, Adamawa State, Nigeria', Proceedings of the 15th
International Academic Conference, Rome, Italy, International Institute of Social and Economic Sciences (IISES), 14 April 2015, pp.19-28, viewed 14 January 2019 from http://www.iises.net/proceedings/international-academic-conference-rome/ fromt-page.

Adebayo, A.A., Onu, J.I., Adebayo, E.F. \& Anyanwu, S.O., 2012, 'Farmers' awareness, vulnerability and adaptation to climate change in Adamawa State, Nigeria', British Journal of Arts and Social Science 9(II),104-115

Ake, C., 1981, A political economy of Africa, Longman Group Limited, London, UK.

Akhakpe, I.B., 2018, 'Climate change and sustainable development in Nigeria: Limitations and opportunities', in I.M. Bolajoko (ed.), Handbook of research on environmental policies for emergency management and public safety, pp. 209-222, IGI Global, Lagos, Nigeria.
Akuwudike, C.H., Igbokwe-Ibeto, C.J. \& Achilike, N.I., 2018, 'Imperative of climate change awareness on the sustainability of small and medium scale enterprises (SMEs) in South East, Nigeria', Review of Public Administration and Management 7(14), 32-43.

Allen, J., 2004, Tango in the atmosphere: Ozone and climate change, Earth Observatory, viewed 07 June 2019, from https://earthobservatory.nasa.gov/ blogs/climateqa/are-the-ozone-hole-and-global-warming-related/

Anazodo, R.O., Igbokwe-lbeto, C.J., Osawe, C.O. \& Nkah, B.C., 2014, 'Graaroot leadership and sustainable development in Nigeria: Periscoping the impediments and exploring the imperatives', Journal of Sustainable Development 16(6) and explorir 1125 .

Bemisaya, O., 1985, 'An evaluation of the operation feed the nation policy in Nigeria', The Nigerian Journal of Economic and Social Studies 7(1), 54-63.

Burke, M.B. \& Lobell, D., 2010, 'Climate effects on food security: An overview in Climate Effects on Food Security: An Overview', in D. Lobell \& M. Burke (eds.) Climate Change and Food Security, pp. 13-30, Advances in Global Change Research 37, Springer, Dordrecht, viewed 07 March 2019, from http://doi. org/10.1007/978-90-481-2953-9_2.

Elegalam, D., 2009, 'An appraisal of agricultural policy of Nigeria during military regime', Proceedings of the Annual Conference of the Nigerian Economic Society, Ibadan, Nigeria, University of Ibadan, pp. 20-32.

Emefiele, G., 2018, 'Economy may slip back into recession', Punch Newspaper, 26 September 2018, viewed 10 November 2018, from https://www.africanews. com/2018/09/26/nigeria-economy-may-slip-back-into-recession-central-bank//.

European Center of Sustainable Development (ECSD)., 2016, Sustainable development, climate politics and EU-leadership: A historical-comparative analysis, viewed 13 December 2018, from http://www.global.ucsb.edu/sites/ secure.Isit.ucsb.edu.gisp.d7-2/files/sitefiles/people/Clemencon $\% 202016 \% 20$ -\%20EJSD $\% 20-\% 20$ Sustainable $\% 20$ Development $\% 20$ Climate $\% 20$ Cha nge $\% 20$ and $\% 20$ EU\%20Leadership\%20310-613-1-PB.pdf.

Fatile, O.J. \& Igbokwe-Ibeto, C.J., 2012, 'Nigerian public sector and the challenges of human capital development: The way forward', Scottish Journal of Arts, Socia Sciences and Scientific Study 1(2), 11-23.

Federal Government of Nigeria (FGN)., 2007, The report of the political bureau, Mass Mobilization for Self Reliance, Social Justice, and Economic Recovery (MAMSER), Abuja, Nigeria.

Food and Agricultural Organisation (FAO), 2017, 'Food security and nutrition in the age of climate change', Proceedings of the International Symposium organized by the government of Québec in collaboration with FAO Québec City, September 24-27, 2017, viewed 07 March 2019, from http://www.fao.org/3/CA1334EN/ ca1334en.pdf.

Food and Agricultural Organisation (FAO), 2011, The state of food insecurity in the world: How does international price volatility affect domestic economies and food security?, Rome, Italy, viewed 07 March 2019, from http://www.fao. org/3/a-i2330e.pdf.

Gamble, A., 1981, An introduction to modern social and political thought, Macmillan, London, UK

Igbokwe-Ibeto, C.J., Okoye, C.J. \& Nnaji, I.L., 2018, 'Open grazing, food insecurity and sustainable human development in Nigeria: A horn of dilemma', Paper accepted for presented at the 1st International Conference, Department of Public Administration, Enugu State University of Science and Technology, October 24-26, pp.102-118.

Igbokwe-Ibeto, C.J., Osakede, K.O., Nkomah, B.B. \& Kinge, R.F., 2016, 'Treasury single account, transparency and accountability in public finance management in Nigeria: The journey so far, Africa's Public Service Delivery and Performance Review 4(2), 342-359. https://doi.org/10.4102/apsdpr.v4i2.116

Igbokwe-Ibeto, C.J., Akhakpe, I. \& Oteh, C.O., 2012, 'Poverty and sustainable socioeconomic development in Africa: The Nigerian experience', Asian Economic and Financial Review 2(2), 367-381.

International Monetary Fund (IMF), 2015, Gross domestic product (GDP) by country/ statistics from IMF, 1980-2023, viewed 13 December 2018, from https://knoema. com/tbocwag/gdp-by-country-statistics-from-imf-1980-2023.

Logan, E., 2015, 5 Ways climate change is challenging our food security, viewed 14 March 2019, from https://www.earthhour.org/content/5-ways-climate-changechallenging-our-food-security.

Maslow, A.H., 1943, 'A theory of human motivation', Psychological Review 50(4), 370-396, viewed 07 June 2019, from http://thepeakperformancecenter.com/ educational-learning/learning/principles-of-learning/maslows-hierarchy-needs/)

Moreland, S. \& Smith, E., 2012, Modelling climate change, food security, and population, Futures Group with MEASURE Evaluation, Washington, DC, viewed 10 March 2019, from https://www.measureevaluation.org/resources/publications/ sr-12-69.

National Bureau of Statistics., 2017, Climate change and food crisis, Government Press, Abuja, Nigeria.

Okigbo, P., 2007, Essays in the public philosophy of development, Fourth Dimension Publishers, Enugu, Nigeria.

Olaniran, Y., 2012, Review of the state of agricultural enterprises in Nigeria, Second Lagos State University CDDS Lecture Series, Nigeria Institute of International Affairs, Lagos, Nigeria.

Olufemi, M., 2018, 'Climate change and its effects on present-day Nigeria', Nigerian Tribune, Tuesday 14th, May, viewed 02 February 2018, from https:// tribuneonlineng.com/130019/

Osaghae, E., 2011, The cripple giant: Nigeria, since independence, Hurst Publishing Company, London, UK. 
Osakede, K.O., Ijimakinwa, S.O. \& Adesanya, T.O., 2016, 'Climate change and its impacts on the development of coastal communities in Nigeria', International Journal of Accounting Research 2(9), 1-12. https://doi.org/10.12816/0027250

Solomon, T. \& Marcin, B. 2014, 'Nigeria Vision 20:2020 can dream become reality? Evidence from national accounts', Journal of International Studies 7(3), 162-170. https://doi.org/10.14254/2071-8330.2014/7-3/15

Thakrar, J. \& Minkley, G., 2015, 'Re-imaging the Eastern Cape Province: Sustaining human development from the perspective of state, civil society and the university' Africa's Public Service Delivery and Performance Review 3(2), 127-148. https:// doi.org/10.4102/apsdpr.v3i2.83

United Nations (UN), 2018, Warns climate change is driving global hunger, viewed 14 March 2019, from https://unfccc.int/news/un-warns-climate-change-is-driving-global-hunger.
United Nations Development Programme (UNDP), 2018, Human development index (HDI), viewed 10 April 2017, from http://hdr.undp.org/en/content/humandevelopment-index-hdi.

United Nations (UN), 2011, 'Climate change and global sustainability resources', COP17 Conference, Durban, South Africa, 28 November to 11 December 2011 viewed10 March 2019, from https://en.wikipedia.org/wiki/2011_United_ Nations_Climate_Change_Conference.

World Bank, 2012, Annual report on global economy and climate change, Agency Press, Geneva, Switzerland.

Von Grebmer, K. \& Hossain, N., 2017, Global hunger index: The inequality of hunger, International Food Policy Research Institute, Washington, DC. 